\title{
Short Communication: Egg harvesting and local conservation of Moluccan Scrubfowl (Eulipoa wallacei) in the Maluku Islands, Indonesia
}

\author{
RADIOS SIMANJUNTAK ${ }^{1}$, MASITAH YUSNIAR ${ }^{1}$, YUNIUS M. SAMALUKANG ${ }^{1}$, FIKTOR IMANUEL BOLEU ${ }^{1, \vartheta}$, \\ ANI MARDIASTUTI ${ }^{2}$, VINCENTIA WIDYASARI ${ }^{3}$, JIHAD SULFANI UDIN ${ }^{3}$ \\ ${ }^{1}$ Faculty of Natural Sciences and Engineering Technology, Universitas Halmahera. Jl. Raya Wari, Wari Ino, Tobelo, North Halmahera 97762, \\ North Maluku, Indonesia. Tel.+62-82194360263”email: fiktor.imanuelhanna @ gmail.com \\ ${ }^{2}$ Department of Forest Resources Conservation and Ecotourism, Institut Pertanian Bogor. Jl. Lingkar Akademik Kampus IPB, Dramaga, \\ Bogor 16680, West Java, Indonesia \\ ${ }^{3}$ Burung Indonesia. Jl. Dadali No. 32, Tanah Sareal, Bogor 16161, West Java, Indonesia
}

Manuscript received: 31 March 2020. Revision accepted: 12 June 2020.

\begin{abstract}
Simanjuntak R, Yusniar M, Samalukang YM, Boleu FI, Mardiastuti A, Widyasari V, Udin JS. 2020. Short Communication: Egg harvesting and local conservation of Moluccan Scrubfowl (Eulipoa wallacei) in the Maluku Islands, Indonesia. Biodiversitas 21: 3018-3024. This study was conducted at four locations in Central Maluku and North Halmahera, which have been used as nesting ground habitats of the Moluccan Scrubfowl (Eulipoa wallacei), an endemic bird of the Maluku Islands, Indonesia. The objective of this study was to record and analyze the egg harvesting and local conservation of Moluccan Scrubfowl in four locations in the Maluku Islands: Simau, Kao, Haruku, and Kailolo. The results showed that a relatively large number of harvested eggs were found in Simau (Halmahera Island) and Kailolo. In Kailolo, the total number of eggs harvested was 21,707 per year. The local community has the initiative to conserve this bird by establishing local regulations, called sasi. The Haruku community gave a portion of the eggs to Kewang, a customary institution authorized to manage the natural resources, to be hatched semi-naturally around the Kewang House. Likewise, the Salabia youth organization in Simau, together with landowners, developed a semi-natural hatchery for the Moluccan Scrubfowl eggs.
\end{abstract}

Keywords: Haruku, Kailolo, Kao, Sasi, semi-natural hatchery, Simau

\section{INTRODUCTION}

The megapode family (Megapodiidae) has highly unique breeding biology in which they incubate their eggs using heat from environmental sources, such as solar energy, volcanic activity, and microbial decomposition, and in which chicks are completely independent after hatching. In other words, megapodes have been released from the constraints of post-hatching parental care (Jones et al 1995; Harris et al 2014; Pangau-Adam and Brodie 2019).

Moluccan Scrubfowl (Eulipoa wallacei) is a megapode whose biogeographic range is in the Wallacea region (Harris et al 2014), and it is an endemic bird of the Maluku Islands, Indonesia (BirdLife International 2001; Heij and Rompas 2011; Sjafani et al. 2015). According to historical records, the bird is distributed across the provinces of Maluku and North Maluku, including the islands of Buru, Seram, Ambon, Bacan, Halmahera, and Ternate. In Maluku province, the population has spread in the Central Maluku District, especially in the villages of Haruku and Kailolo. Meanwhile, in North Maluku province, its habitat distribution includes Galela (Tiabo), Loloda, Ibu, Mount Gamkonora, Oketai River, Tolawi River, Kali Batu Putih, Mount Sibela in Bacan, and some other areas (Dekker et al 2000; BirdLife International 2001; 2020). Unfortunately, many nesting ground habitats of the Moluccan Scrubfowl have been damaged, and it is, therefore, difficult to find this species in some areas.

The local people in the Maluku Islands have utilized Moluccan Scrubfowl eggs as an important source of protein and livelihood (Heij 1997; BirdLife International 2008; Heij and Rompas 2011). Since 1994, the Moluccan Scrubfowl has been categorized as vulnerable by the International Union for Conservation of Nature (IUCN). The total population is between 20,000 and 50,000 individuals but is suspected to be decreasing rapidly due to the uncontrolled and unsustainable harvesting of eggs, a reduction in the number of adults due to hunting pressure and introduced predators, and the fragmentation of habitats (IUCN 2020).

The efforts of the Indonesian Government to protect this endemic bird through the protection of the Megapodiidae family is outlined in Government Regulation Number 7/1999 concerning the preservation of flora and fauna. The Ministry of Environment and Forestry has also made the Moluccan Scrubfowl a protected species through Regulation P.106/Menlhk/Setjen/Kum.1/12/2018 of the Minister of Environment and Forestry of the Republic of Indonesia.

The objective of this study was to record and analyze the egg harvesting and local conservation of Moluccan Scrubfowl in four locations in the Maluku Islands. 
Harvesting techniques, the number of harvested eggs, and efforts to conserve this species through semi-natural hatching programs were also investigated.

\section{MATERIALS AND METHODS}

\section{Study Site}

This research was conducted from April to August 2019 in four different locations of the Molluccan Scrubfowl's nesting ground habitat, namely the villages of Simau, Kao, Haruku, and Kailolo. Simau and Kao are in the North Halmahera District (Figure 1); both villages are located in the coastal area at an altitude of 25-50 m asl. The North Halmahera District has an average temperature of $24.4^{\circ} \mathrm{C}$, rainfall of $175.2 \mathrm{~mm}$, and relative humidity of $87.8 \%$. Simau $\left(1^{\circ} 50^{\prime} 55.86 " \mathrm{~N}, 127^{\circ} 50^{\prime} 33.733^{\prime \prime} \mathrm{E}\right)$ has an area of 1.6 $\mathrm{km}^{2}$ and a population of around 1,046 people, while Kao $\left(1^{\circ} 9^{\prime} 27.657^{\prime \prime} \mathrm{N}, 127^{\circ} 54^{\prime} 10.579^{\prime \prime} \mathrm{E}\right)$ has an area of $7.5 \mathrm{~km}^{2}$ and a population of around 1,135 people.

The other study sites were two villages in the Haruku Island Sub-district, Central Maluku District, called Haruku $\left(3^{\circ} 36^{\prime} 32.04^{\prime \prime S}, 128^{\circ} 25^{\prime} 4.32^{\prime \prime E}\right)$ and Kailolo $\left(3^{\circ} 32^{\prime} 18.66^{\prime \prime S}\right.$, $\left.128^{\circ} 24^{\prime} 52,62^{\prime \prime E}\right)$. The two villages have equal areas of 13 $\mathrm{km}^{2}$, with altitudes ranging from 0 to $700 \mathrm{~m}$ asl. The population of Haruku is 2,336 people, while that of Kailolo is 4,012 . The average temperature of Haruku Island Subdistrict ranges between 25.2 and $27.8^{\circ} \mathrm{C}$, the rainfall ranges between 16 and $888 \mathrm{~mm}$, and the relative humidity ranges between $83 \%$ and $92 \%$.

\section{Method}

Data collection was conducted by recording the number of eggs harvested and other relevant information related to the egg harvesting, as well as interviews with local people. As the Moluccan Scrubfowl bury their eggs in a communal sandy beach at night (Heij and Rompas 2011), the egg harvesting by local people is generally carried out in the morning. The data for the number of harvested eggs were obtained from village informants during April 2019.

In Simau, data collection from four landowners was assisted by two young informants from a youth organization called "Salabia". In Kao and Haruku, the data collected from the nesting grounds was assisted by one informant from each village. In Kailolo, four villagers who harvested the Moluccan Scrubfowl eggs assisted the documentation of the number of eggs they harvested, but the data for one-year production was available only for the year 2017-2018.

Data for the Moluccan Scrubfowl semi-natural hatching program was collected from Simau and Haruku. In Simau, the data was collected in August 2018, January 2019, and March 2019 by researchers from the Halmahera University, while in Haruku, the data used was rather old (2016) and collected by the Baileo Foundation. The data includes hatching and egg incubation techniques, the number of eggs hatched, care for the young Moluccan Scrubfowl in cages, and their release. Other information related to the efforts to conserve the Moluccan Scrubfowl includes local government regulations and the implementation of the local sasi conservancy principles, especially in Kailolo for egg harvesting through an auction system and in Haruku for egg protection.

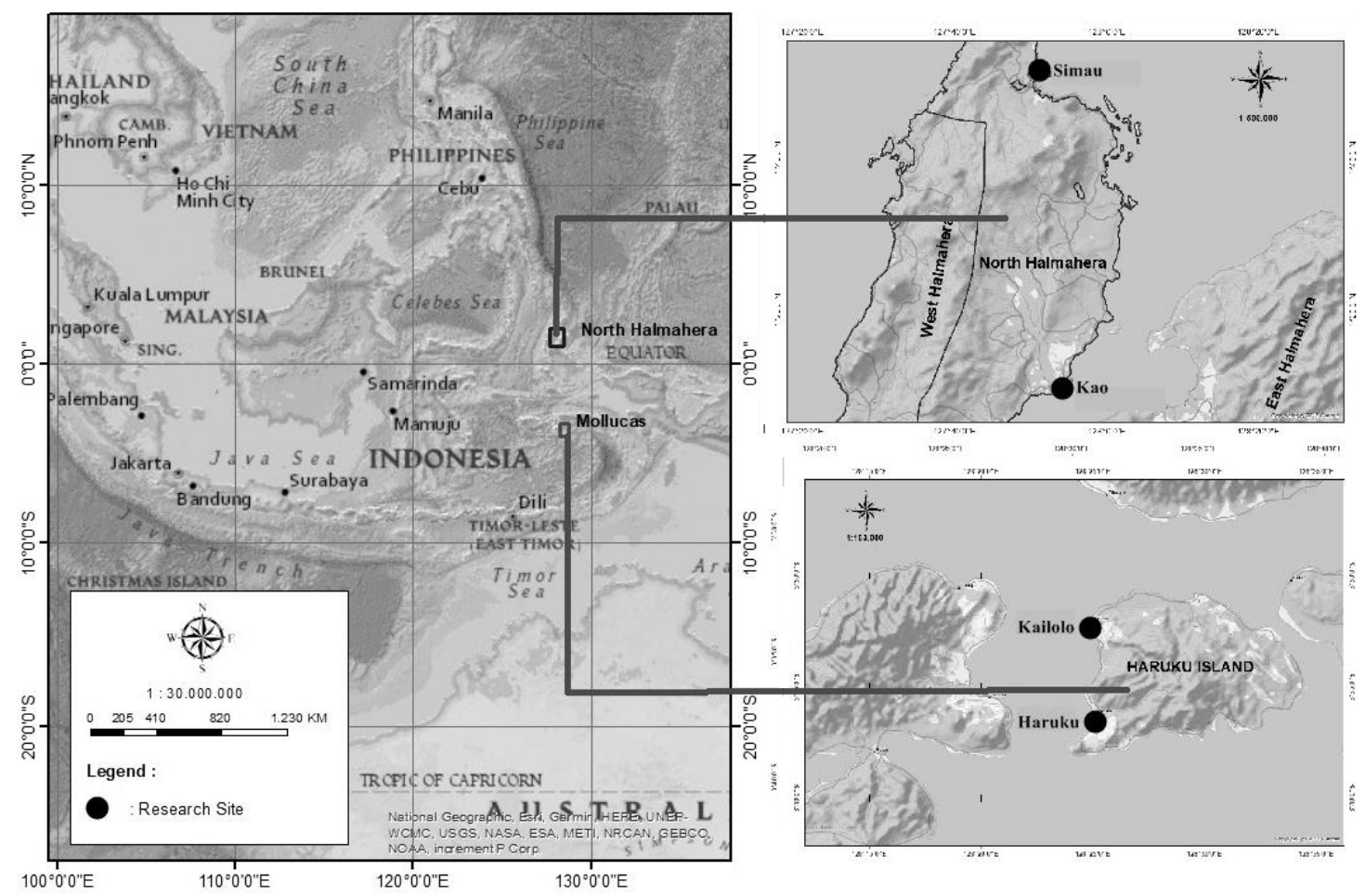

Figure 1. Moluccan Scrubfowl nesting ground study sites in the Maluku Islands: Simau, Kao, Haruku, and Kailolo (black dots). 


\section{RESULTS AND DISCUSSION}

\section{Use of Moluccan Scrubfowl Eggs}

Local communities in the study areas have been using the Moluccan Scrubfowl eggs for generations, both for their own consumption and for income generation. Some villages have already developed measures to ensure the sustainability of the species and the harvestable eggs. In Simau, a portion of the harvested eggs is used in a seminatural hatching program. In Kailolo and Haruku, the use of eggs has been regulated through a traditional custom called sasi. To control the implementation of sasi, a traditional organization was established, called kewang.

The harvest system through sasi in Kailolo differs slightly from that in Haruku. In Kailolo (specifically in Tanjung Maleo), the area designated as sasi is allowed to be harvested, but this is regulated through an auction system. The auction winner has the right to conduct the daily harvest of eggs for one year. In Haruku, the area designated as sasi is prohibited from being harvested, but the local people are still allowed to harvest eggs from areas not designated as sasi.

Egg harvestings are conducted by excavating the Moluccan Scrubfowl's nesting ground along the beach with bare hands, at a depth between $60 \mathrm{~cm}$ and $80 \mathrm{~cm}$ (Figure 2). The Moluccan Scrubfowl nesting grounds at all the study sites are relatively close to settlements, at a distance of 600 m or less (Table 1).

In Simau, egg harvesting is carried out by landowners around Kali Hela. Moluccan Scrubfowl egg harvesting in Kailolo is carried out every day throughout the year and was well documented compared to the data from the other three study sites. Data from April 2017-March 2018 showed that the annual harvest in Kailolo was 21,707 (Table 2), with June to August being the months with the lowest production.

\section{Semi-Natural Egg Hatching Program}

As an effort to conserve the Moluccan Scrubfowl, the local people in Simau and Haruku have established a seminatural egg hatching program, in which some harvested eggs are buried below the sandy soil in an enclosure nearby
(Figure 3). When the eggs hatch and the chicks emerge from the enclosure's sandy soil after approximately 60 days of natural incubation, the chicks are fed with rice bran and sometimes ants (from ant hives) as an additional food until they are ready to be released, after about two weeks in Simau or after about three months in Haruku.

In Simau, the semi-natural egg hatching program is conducted by the Salabia Youth Community, in collaboration with landowners. Hatching success was high in January and March but much lower in August (Table 3), probably due to high rainfall. Overall, the survival percentage from egg to release was $64.2 \%(n=81)$.

In Haruku, the hatching program is administered by Kewang, a customary institution authorized to manage the natural resources of the community and supervise the implementation of customary rules. The Kewang of Haruku carries out the activities of hatching eggs and of raising and releasing the Moluccan Scrubfowl chicks into the wild. Hatching success varied greatly, and there was a period (May 2016) when there were no hatchings at all, most likely because of heavy rainfall, similar to the weather conditions in Simau. The survival percentage was $52.9 \%$, lower than in Simau's hatching program.

Table 2. Number of eggs harvested during a one-year auction period (April 2017-March 2018) in Kailolo (Tanjung Maleo) in a sasi area, based on records from egg collectors.

\begin{tabular}{lc}
\hline Month & Number of harvested eggs \\
\hline April 2017 & 2,618 \\
May 2017 & 1,518 \\
June 2017 & 604 \\
July 2017 & 351 \\
August 2017 & 742 \\
September 2017 & 1,639 \\
October 2017 & 2,753 \\
November 2017 & 2,533 \\
December 2017 & 2,901 \\
January 2018 & 2,019 \\
February 2018 & 2,244 \\
March 2018 & 1,785 \\
& \\
Monthly average & 1,809 \\
Total (12 months) & 21,707 \\
\hline
\end{tabular}

Table 1. Moluccan Scrubfowl egg harvesting in the study areas in April 2019

\begin{tabular}{|c|c|c|c|c|c|c|}
\hline \multirow{2}{*}{ Parameter } & \multicolumn{2}{|c|}{ Simau } & \multirow{2}{*}{ Kao } & \multirow{2}{*}{$\begin{array}{c}\text { Kailolo } \\
\text { (Sasi Area) }\end{array}$} & \multicolumn{2}{|c|}{ Haruku } \\
\hline & Harvested & Unharvested $^{1}$ & & & Sasi Area $^{2}$ & Non-Sasi Area \\
\hline Distance to settlement (m) & 600 & 600 & 500 & 400 & 100 & 50 \\
\hline Nesting ground area $\left(\mathrm{m}^{2}\right)$ & 7,332 & 7,332 & 6,940 & 3,704 & 2,500 & n.a. ${ }^{3}$ \\
\hline Days of harvest per month & 23 & 23 & 17 & 30 & 0 & 19 \\
\hline Total number of harvested eggs & 947 & 947 & 58 & 1,643 & 0 & 364 \\
\hline Egg production per $100 \mathrm{~m}^{2}$ & 12.9 & 12.9 & 0.8 & 44.3 & 0 & n.a. \\
\hline Number of eggs (Simau only) & 812 & 135 & - & - & - & - \\
\hline Harvest percentage & 85.7 & 14.3 & 100 & 100 & 0 & n.a $a^{4}$ \\
\hline $\begin{array}{l}\text { Average number of harvested eggs per } \\
\text { day (mean } \pm \text { SD) }\end{array}$ & $35.3 \pm 5.3$ & $5.9 \pm 1.9$ & $3.4 \pm 1.7$ & $54.8 \pm 21.4$ & 0 & $19.2 \pm 3.8$ \\
\hline
\end{tabular}

Note: ${ }^{1}$ Dedicated to the semi-natural hatchery system. ${ }^{2}$ No harvest activity for Moluccan Scrubfowl eggs in the sasi area (in Haruku only). ${ }^{3}$ The number of eggs that are not harvested is not clearly known (some of the excavated eggs were given to Kewang to be hatched semi-naturally at the Kewang House location). 4Exact data not available. The sasi-free area covered the area of Tanjung Wairusi to Tanjung Waimaru (Gaspersz and Saiya 2018). 


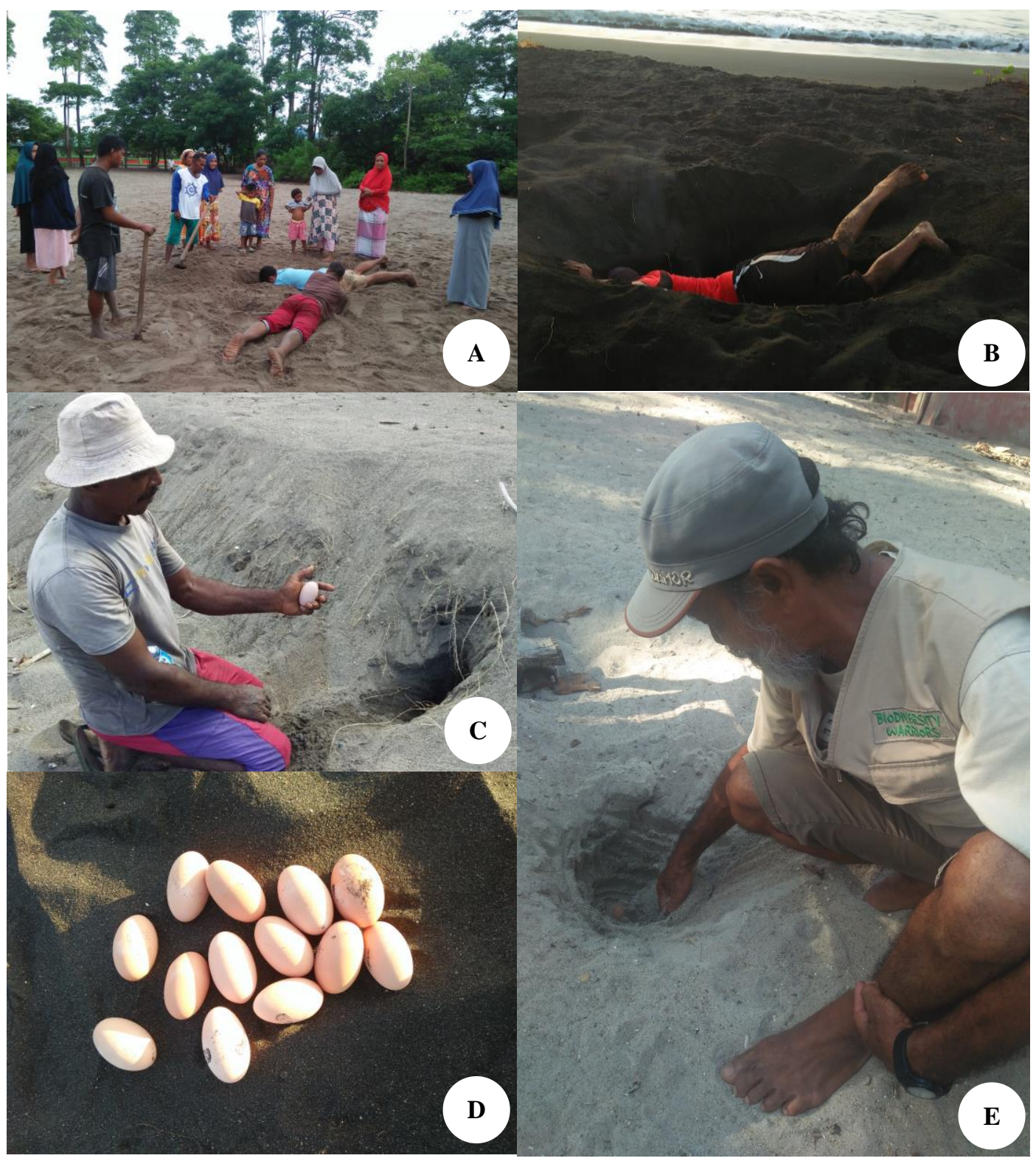

Figure 2. Egg-harvesting techniques in the study areas: A. Egg harvesting in Kailolo, B. Egg harvesting in Simau, C. Egg harvesting in Kao, D. Harvested eggs from Simau, E. Egg-laying spot in Haruku. Photographs by RS.

\section{Local regulation to conserve the bird species}

For the community in Halmahera, Moluccan Scrubfowl eggs are usually used as a gift or a souvenir for visiting guests and tourists. In other regions, such as in Kailolo Village, the harvesting of these eggs has a high impact on the local economy and social life. The local government has been conducting auctions to harvest the Moluccan Scrubfowl eggs, and the funding from these auctions is used for the construction and maintenance of mosques in Kailolo. Because of the funding generated from the eggs, the local people continue to harvest eggs in other areas in the Maluku Islands.

As an effort to support conservation, the village government of Kao issued a village regulation (number
03/2017) concerning environmental protection, which included prohibitions on hunting, shooting, and catching all bird species in coastal areas and mangrove forests. Further, on 2 October 2018, facilitated by non-governmental organizations, the Kao villagers implemented a six-month moratorium on the collection of Moluccan Scrubfowl eggs to increase the population of the birds. In addition, the Kao village government took the initiative to encourage the provincial government to establish Kao as an Essential Ecosystem Area (EEA), which was supported by local universities, non-government organizations, and the local government of the North Halmahera District through the EEA Management Collaboration Forum based on North Halmahera Regent Decree Number 031/267/HU/2019. 
Table 3. The semi-natural Moluccan Scrubfowl egg hatching programs in Simau and Haruku, Maluku, Indonesia

\begin{tabular}{|c|c|c|c|c|c|c|c|}
\hline \multirow{2}{*}{ Location } & \multirow{2}{*}{ Month } & \multirow{2}{*}{$\begin{array}{c}\text { Number of } \\
\text { eggs }\end{array}$} & \multicolumn{2}{|c|}{ Hatched eggs } & \multicolumn{2}{|c|}{ Surviving chicks released } & \multirow{2}{*}{$\begin{array}{c}\text { Survival } \\
\text { percentage }^{1}\end{array}$} \\
\hline & & & Number & $\%$ & Number & $\%$ & \\
\hline \multirow[t]{4}{*}{ Simau } & Aug 2018 & 26 & 7 & 26.9 & 7 & 100.0 & 26.9 \\
\hline & Jan 2019 & 20 & 18 & 90.0 & 15 & 83.3 & 75.0 \\
\hline & Mar 2019 & 35 & 34 & 97.1 & 30 & 88.2 & 85.7 \\
\hline & Total & 81 & 59 & 72.8 & 52 & 88.1 & 64.2 \\
\hline \multirow[t]{4}{*}{ Haruku } & Feb 2016 & 44 & 21 & 47.7 & 20 & 95.2 & 45.4 \\
\hline & May 2016 & 40 & 0 & 0.0 & 0 & 0.0 & 0.0 \\
\hline & Sep-Oct 2016 & 158 & 130 & 82.3 & 108 & 83.1 & 68.3 \\
\hline & Total & 242 & 151 & 62.4 & 128 & 84.8 & 52.9 \\
\hline
\end{tabular}

Note: ${ }^{1}$ from egg to successful release

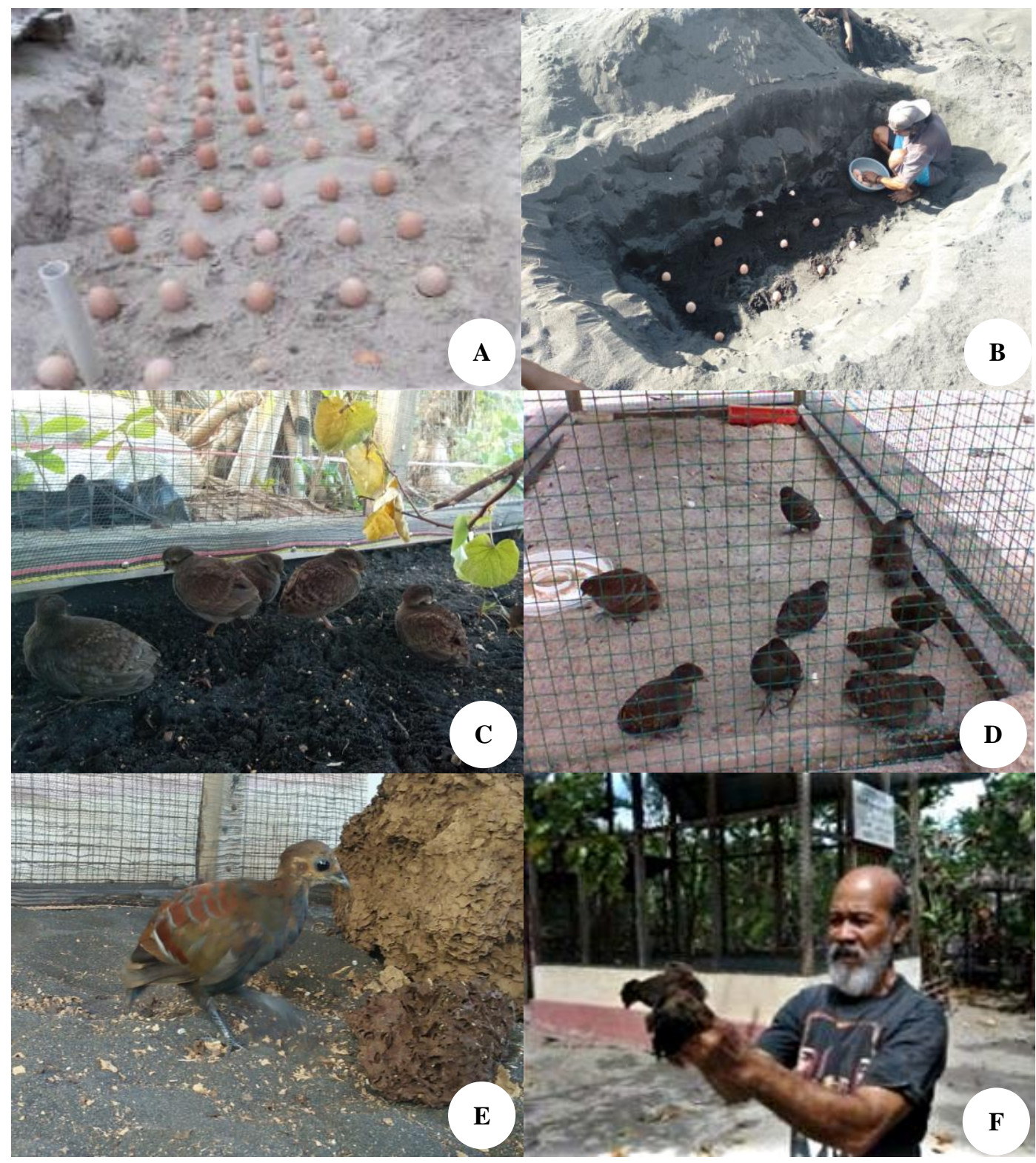

Figure 3 Semi-natural hatching program of the Moluccan Scrubfowl in Simau and Haruku: A. Eggs to be semi-naturally incubated in Haruku, B. Semi-natural incubation in Simau, C-D. Hatchings in the enclosures, E. A week-old chick in Simau enclosure, F. Chicks ready to be released in Haruku. Photographs by Baileo Maluku/Rony Siwabessy (A, D, F) and Halmahera University/Ronald Kondo Lembang $(\mathrm{B}, \mathrm{C}, \mathrm{E})$ 


\section{Discussion}

Moluccan Scrubfowl egg-harvesting activity in the Maluku Islands has been well documented by Heij and Rompas (2011), who recorded two places with relatively high egg yields: Galela and Kailolo. Heij $(2001 ; 2005)$ and Heij and Rompas (2011) reported the intensity of egg harvesting in Tanjung Maleo in Kailolo from 1987 to 2010, which was concentrated in the dry and rainy seasons. In the early period of their reports, in 1987/1988, the number of eggs harvested was 18,260, and the most eggs harvested was 37,712 , in 1996/1997. In the following years, the number of eggs harvested decreased from 19,279 in $2000 / 2001$ to 18,989 in $2006 / 2007$ and 17,730 in $2009 / 2010$.

The current research showed an increasing number of eggs harvested in 2017/2018 (21,707 eggs), which indicates that the number of laying female birds has increased. A visit report to Galela (North Halmahera) in 1995 found as many as 45 Moluccan Scrubfowl egg-laying areas, with each area producing an estimated 3,000 eggs per year, for a total of 135,000 eggs (Heij and Rompas 2011). The number of laying females was estimated at 13,000-14,000 in Galela (Heij et al. 1997; BirdLife International 2016). Interestingly, Sjafani et al (2015) reported different results, with estimates of the Moluccan Scrubfowl population in three locations in Galela (UwoUwo, Tiabo, and Denamabobane) in 2011 and 2012 of $5,505.09 \pm 4.26$ and $5,000.60 \pm 5.90$ individuals, respectively.

This study found that the number of eggs harvested in the Simau (Galela) region in April 2019 was $35.3 \pm 5.3$, with a total of 812 eggs. Data for the egg harvesting (i.e. only one month at one egg-laying location) makes it difficult to estimate the population of Moluccan Scrubfowl in this region.

The conservation of Moluccan Scrubfowl in Haruku began in 1997 by relocating fresh eggs from the nesting ground in Tanjung Maleo in Kailolo (Heij and Rompas 2011). The success of the Moluccan Scrubfowl seminatural hatchery program around the Haruku Kewang House has resulted in an increasing number of spawning birds, both in sasi areas and surrounding non-sasi areas, as indicated by the total number of eggs harvested in April 2019 (364 eggs). The limited information on the number of eggs given to the Haruku Kewang for conservation purposes makes it difficult to determine the percentage of eggs not harvested in this region.

Traditional knowledge and institutions in Haruku and Kailolo play an important role in ensuring the sustainability of Moluccan Scrubfowl. Local conservancy principles are known as sasi, which comprise rules governing the management and use of natural resources at sea and on land, are based on customary agreements and only apply to the sasi area of that village (Xiuping et al 2010; Kaya et al 2018; Gaspersz and Saiya 2018). In Haruku's customary government, saniri a,lo'osi aman harukui acts as a customary assembly and sets rules related to sasi, and the monitoring of sasi is delegated to Kewang. (Gaspersz and Saiya 2018).
The consistent implementation of customary rules related to the conservation of the Moluccan Scrubfowl in Haruku and Kailolo can guarantee the conservation of these endemic animals and, at the same time, the sustainable use of eggs for the local community. The support of various parties, such as landowners, village governments, universities, and non-government organizations, further improves the efforts to conserve the nesting ground habitats of Moluccan Scrubfowl.

Sasi is not only found in Haruku and Kailolo; as a part of traditional natural resource conservation practices, sasi has existed for generations in various regions in the Maluku Islands. Kaya et al (2018) reported that there are forms of sasi in West Seram District, called Sasi Hutan (Hutan: forest), Sasi Telaga Raja, Sasi Gereja (Gereja: church), Sasi Morekau, Mangrove Sasi, and Sasi Laut (Laut: sea). In Masawoy, South Buru District, there is also Sasi Lola (Haulussy et al 2020). Sasi is a cultural conservation activity carried out by the communities in Maluku and is a traditional heritage that influences how people live in harmony with nature (Melay and Putrawan 2017).

\section{ACKNOWLEDGMENTS}

We gratefully thank the CEPF (Critical Ecosystem Partnership Fund) and Burung Indonesia for financial support. We also thank the communities of Simau, Kao, Haruku, and Kailolo, who kindly gave us much-needed information.

\section{REFERENCES}

BirdLife International. 2001. Threatened Birds of Asia: The BirdLife International Red Databook. BirdLife International, Cambridge, UK.

BirdLife International. 2008. Megapode eggs are an important source of food to many Indo-Pacific communities. http://www.birdlife.org [22 April 2020].

BirdLife International. 2016. Eulipoa wallacei. The IUCN red list of threatened species 2016: e.T22678632A92782396. DOI: 10.2305/IUCN.UK.2016- 3.RLTS.T22678632A92782396.en. [22 April 2020].

BirdLife International. 2020. Species factsheet: Eulipoa wallacei. http://www.birdlife.org [22 April 2020].

Dekker RWRJ, Fuller RA, Baker GC. 2000. Megapodes: Status survey and conservation action plan 2000-2004. IUCN, Gland, Switzerland and Cambridge, UK.

Gaspersz EJ, dan Saiya HG. 2018. Mapping of 'Sasi' as local wisdom in Haruku Village and Kailolo Village, Haruku Island, District of Middle Moluccas. National Seminar on Geomatics, Use and Development of Geospatial Information Products in Supporting National Competitiveness. [Indonesian].

Harris RB, Birks SM, Leaché AD. 2014. Incubator birds: Biogeographical origins and evolution of underground nesting in megapodes (Galliformes: Megapodiidae). J. Biogeogr 41 (11): 2045-2056. doi. 10.1111/jbi.12357.

Haulussy RH, Najamuddin, Idris R, Agustang ADMP. 2020. The sustainability of the Sasi Lola tradition and customary law (Case study in Masawoy Maluku, Indonesia). Intl J Sci Technol Res 9 (2): 5193-5195.

Heij CJ. 1997. The behaviour of the Mollucan Megapode, Eulipoa wallacei (Aves: Megapodidae) in nesting grounds. Treubia 31 (2): 169-176. 
Heij CJ, Rompas CFE, Moeliker CW. 1997. The biology of the Moluccan megapode Eulipoa wallacei (Aves, Galliformes, Megapodiidae) on Haruku and other Moluccan islands; Part 2: Final report. DEINSEA: Jaarbericht van het Natuurmuseum, Rotterdam.

Heij CJ. 2001. The biology of the Moluccan megapode Eulipoa wallacei (Aves, Galliformes, Megapodiidae) on Haruku and other Moluccan Islands; Part 3: Update of data until 2001. DEINSEA 8: 229-241.

Heij CJ. 2005. The biology of the Moluccan megapode Eulipoa wallace (Aves, Galliformes, Megapodiidae) on Haruku and other Moluccan Islands; Part 4: Update of data until 2005. DEINSEA 11: 159-168.

Heij CJ, Rompas CFE. 2011. Ecology of the Moluccan Megapode Eulipoa wallacei on Haruku and other Moluccan islands, Indonesia. Rotterdam/Ambon. [Indonesian].

IUCN (International Union for Conservation of Nature and Natural Resources). 2020. The IUCN red list of threatened species. Version 2020-1. www.iucnredlist.org.

Jones DN, Dekker RWRJ, Roselaar CS. 1995. The Megapodes (Bird families of the world). Oxford University Press, Oxford, UK.
Kaya IRG, Hutabarat J, Bambang AN. 2018. "Sasi": A new path to sustain seaweed farming from up-stream to down-stream in Kotania Bay, Moluccas. Int J Soc Ecol Sust Dev 9 (2): 28-36. DOI: 10.4018/IJSESD.2018040103.

Melay S, Putrawan IM. 2017. Improving people knowledge about natural resource conservation by developing instructional packages on ecological concepts related to Sasi culture. Intl J Adv Res 5 (8): 505 510. DOI: 10.21474/IJAR01/5084.

Pangau-Adam MZ, Brodie JF. 2019. Threats to the populations of two endemic brushturkey species in Indonesian New Guinea. J Asia-Pac. Biodivers 12: 488-492. DOI: 10.1016/j.japb.2019.07.005.

Sjafani N, Hakim L, Nurgiartiningsih VMA, Suyadi S. 2015. The habitat and estimation population of Mamoa bird (Eulipoa wallacei) in Galela-Halmahera. J Bio Env Sci 7 (2): 1-9.

Xiuping HHM, Kissya E, Yanes. 2010. Indigenous knowledge and customary law in natural resource management: Experiences in Yunnan, China and Haruku, Indonesia. Asia Indigenous Peoples Pact (AIPP) Foundation, Chiang Mai, Thailand. 